\title{
Clinical and laboratory studies into the pathogenesis of malacoplakia
}

\author{
KLAUS J. LEWIN, ${ }^{1}$ WILliaM R. FAIR, ${ }^{2}$ ROY T. STEIGBIGEL, ${ }^{3}$ CARL D. \\ WINBERG, 1 AND MICHAEL J. DROLLER 2
}

From the Departments of Pathology, ${ }^{1}$ Urology, ${ }^{2}$ and Medicine, ${ }^{3}$ Stanford University Medical School, Stanford, California, USA

SYNOPSIS Three cases of malacoplakia are described. Electron microscopic studies revealed intact bacteria or bacteria in varying states of degradation within phagolysosomes of the malacoplakic $\dot{\omega}$ macrophages. Michaelis-Gutmann bodies arise within the phagolysosomes. These findings suggest $\stackrel{N}{\perp}$ that the bacteria incorporated within the phagolysosomes persist as dense amorphous aggregates음 which later become encrusted with calcium phosphate crystals to form the laminated Michaelis- Gutmann bodies. Possible explanations for the unusual macrophage response in malacoplakia are $: \frac{1}{2}$ (1) infection with an unusual strain of bacteria, (2) an immunological abnormality affecting intracellular killing of organisms, and (3) an abnormality affecting intracellular digestion of organisms. $\vec{\varphi}$ In considering each of the possibilities, we have been unable to detect any unusual strain of infecting. organisms in association with malacoplakia, and in vitro studies have revealed normal $\mathrm{T}$ lymphocyte response to mitogen and normal monocyte bactericidal capacity. According to the history, each patient had reason to have a compromised immune status; in only one, however, was this demonstrated.

Malacoplakia is an uncommon inflammatory disease that was originally described in the bladder (Michaelis and Gutmann, 1902; von Hansemann, 1903) but has subsequently been found in other genitourinary sites (Bleisch and Konikov, 1952; Nation, 1956; Melicow, 1957; Haukohl and Chinchinian, 1958; Blackwell and Finlay-Jones, 1959; Hoffman and Garrido, 1964; Smith, 1965; Green, 1968; Waisman and Rampton, 1968), the gastrointestinal tract (Gonzáles-Angulo et al, 1965; Terner and Lattes, 1965; Yunis et al, 1967; Finlay-Jones et al, 1968; Rywlin et al, 1969; Blackshear, 1970; Di Silvio and Bartlett, 1971; Dockerty, 1972; Ranchod and Kahn, 1972; Lewin et al, 1974), skin (Leclerc and Bernier, 1972), lungs (Gupta et al, 1972), bones (Gupta et al, 1972), and mesenteric lymph nodes (Gonzáles-Angulo et al, 1965; Yunis et al, 1967). It is characterized by an infiltrate of large granular macrophages containing characteristic cytoplasmic calculospherules, the Michaelis-Gutmann (M-G) bodies.

Because of a frequent association of malacoplakia with urinary infections (Bleisch and Konikov, 1952; Scott and Scott, 1958; Gupta et al, 1972), an Received for publication 22 September 1975 infectious agent had long been suspected in the? aetiology of this disease. Also, histochemical studies? of the characteristic M-G bodies indicated that they contained a non-human glycolipid component: possibly of bacterial origin (Terner and Lattes, 1965)

Recently, we (Lewin et al, 1974) and othersi (Leclerc and Bernier, 1972; Le Charpentier et al, ’ 1973; McClurg et al, 1973; Lou and Teplitz, 1974)6 have demonstrated the presence of intracellular? organisms in malacoplakic lesions and have showno that the products of incomplete bacterial digestion remain in phagolysosomes, subsequently becomingo calcified to give rise to the $M-G$ bodies. The reasom for this unusual macrophage response to an in-N fectious organism remains obscure although possible ${ }_{\sigma}^{\omega}$ explanations are (Lewin and Fair, 1974) (1) infection with an unusual strain of organism, or (2) a lesione related to an abnormality affecting intracellularos killing or digestion by macrophages. The present $t_{0}$ paper presents the ultrastructural findings in three cases of malacoplakia (including one case which has been previously reported by us (Lewin et al, 1974) and studies which examine the bactericidal function of monocytes and macrophages in an attempt to evaluate the pathogenesis of this condition. 


\section{Report of Cases}

CASE 1

This 42-year-old white woman with diffuse, poorly differentiated lymphocytic lymphoma first presented in 1968 with generalized lymphadenopathy. She was treated with chlorambucil in 1968, and again in February 1970 for recurrence of lymphoma. Because of leucopenia, chlorambucil was discontinued in June 1970 and prednisone begun. In July 1970 she developed Escherichia coli cystitis unresponsive to numerous antibiotics. On cystoscopy a fungating, firm, sessile, necrotic mass was seen on the dome and the left lateral bladder wall. Biopsy showed malacoplakia.

Radiation therapy was begun in January 1971 for recurrent lymphoma and was delivered over a two-week period to the anterior bladder ( 2500 rads), the midline abdominal nodes ( 3250 rads), the spleen (1050 rads), and the right lateral breast mass. The pelvis was irradiated because of the possibility that lymphatic obstruction by lymphoma might be related to the persistent malacoplakia. During the second week of radiation she developed a firm, tender, suprapubic mass with cutaneous oedema and vesiculation. Abdominal exploration revealed malacoplakia extending from the anterior abdominal wall to the dome of the bladder. Because of recurrent intestinal obstruction due to malacoplakic involvement of the lower anterior abdominal wall, the dome of the bladder, the caecum, the terminal ileum, and a loop of mid-ileum, she underwent bowel resection with ileostomy and ileo-ascending colostomy. In June 1972 she developed bone pain with lytic and blastic lesions due to recurrent lymphoma and was again started on chlorambucil. She died of pneumonia and renal failure two months later.

At necropsy the malacoplakic process was widespread. It was found in the suprapubic region adjacent to the superior ramus and extended into the retroperitoneal tissues, the serosa of the dome of the bladder, the left inguinal region, the mons pubis, the right inguinal region, and the muscles of the thigh and buttocks. Also, there were sinus tracts from the suprapubic and left inguinal regions to the skin, as well as three fistulae between the suprapubic abscess and a segment of ileum and sigmoid colon. Other necropsy findings consisted of widespread lymphoma in the bone marrow and lungs, congestive hepatosplenomegaly, pulmonary oedema, bronchopneumonia, and septic splenitis.

CASE 2

This 33-year-old black woman presented with symptoms of cystitis and microscopic haematuria in January 1973. Physical examination was normal.
She had a history of sarcoidosis diagnosed by a consistent liver biopsy in 1968. She was treated with prednisone until 1971.

Urine culture yielded more than 100000 colonies of $E$. coli sensitive to all standard antibiotics (ampicillin, colistin, gentamicin, kanamycin, nalidixic acid, nitrofurantoin, oxytetracycline, penicillin G, sulphamethizole, chloramphenicol, cephalothin, carbenicillin). Cystoscopy in March 1973 showed wellcircumscribed, raised, yellow-orange mucosal nodules with erythematous borders located in the vicinity of the trigone. Biopsy was interpreted as showing malacoplakia.

Urinary tract infection persisted and by June 1973 cystoscopy revealed more than 20 lesions in the bladder. Urine cultures demonstrated type 02 and type $050 \mathrm{E}$. coli sensitive to standard antibiotics. Treatment consisted of resection, fulguration, and antibiotics.

In December 1973 cystoscopy revealed a decrease in the number of lesions. Urine cultures were sterile but crushed malacoplakic tissue grew 10000 colonies of $E$. coli per millilitre. The patient was placed on long-term trimethoprim-sulfamethoxazole therapy and the urine remained sterile. The patient has since been lost to follow-up.

\section{CASE 3}

This patient was a 51-year-old woman with a carcinoma of the right breast and cerebral metastases. At Stanford she received a full course of whole brain irradiation (3000 rads within a two-week period) with only minimal improvement, and she died three months following diagnosis. During her entire stay at Stanford the patient had a bladder catheter. Urine cultures on two occasions each yielded more than one million colonies of $E$. coli per millilitre. The bacteria were sensitive to all standard antibiotics tested.

At necropsy there was disseminated breast cancer with involvement of the brain, lungs, and adrenals. An incidental finding was malacoplakia of both ureters and the bladder. The distal end of each ureter was studded with numerous raised, yellowwhite, mucosal plaques measuring about $3-5 \mathrm{~mm}$ in diameter. The bladder contained similar plaques which were of greater size and number.

\section{Methods and Results}

CLINICAL INVESTIGATIONS

In all three cases $E$. coli was isolated from the urine. $E$. coli was also grown from the suprapubic fistula in case 1. Although the $E$. coli was not categorized in two cases, types 02 and $050 E$. coli were demonstrated in case 2 from both the urine and crushed malaco- 
plakic tissue. In every case the $E$. coli was sensitive to all standard antibiotics tested.

Skin tests for delayed hypersensitivity, including intermediate purified protein derivative, mumps, histoplasmosis, coccidiodomycosis, and dermatophyton, were performed in cases 1 and 2 . As shown in table I, all skin tests were negative at $\mathbf{4 8}$ hours, except for a positive reaction to mumps antigen in case 2.

Quantitative immunoglobulins were studied, and the results are summarized in table $I$. The immunoglobulin values of case 1 were abnormally low before death and at necropsy. The immunoglobulin and C-3 complement values of case 2 are well within the normal range.

\begin{tabular}{|c|c|c|c|}
\hline & Case 1 & & Case 2 \\
\hline \multicolumn{4}{|l|}{ Skin tests: } \\
\hline Intermediate PPD & - & & - \\
\hline Mumps & 一 & & + \\
\hline Histoplasmosis & 一 & & 一 \\
\hline Coccidiodomycosis & - & & 一 \\
\hline Dermatophyton & - & & - \\
\hline SKSD & - & & - \\
\hline Immunoglobulins $^{1}$ & August 1972 & Necropsy & \\
\hline $\operatorname{IgA}(N$ 90-450) & 40 & 33 & 210 \\
\hline IgM (N 60-280) & 36 & 44 & 236 \\
\hline IgG (N 800-1800) & 475 & 555 & 2250 \\
\hline $\operatorname{lgE}(\mathrm{N} \mathrm{0-400)}$ & - & & 70 \\
\hline \multicolumn{4}{|l|}{ Complement } \\
\hline C-3 (N $109 \mathrm{mg} \%$ ) & & & $109 \mathrm{mg} \%$ \\
\hline PHA stimulation & & & Normal \\
\hline
\end{tabular}

Table I Immunological status of cases 1 and 2

PPD = purified protein derivative; SKSD = streptokinase streptodornase

'Values expressed in milligrams per $100 \mathrm{ml}$
The response of lymphocytes to phytohaem- $\stackrel{\stackrel{0}{\overrightarrow{0}}}{\underline{0}}$ agglutinin (PHA) in case 2 was assayed by incorporation of ${ }^{3} \mathrm{H}$ thymidine and was normal.

\section{PATHOLOGICAL FINDINGS}

Tissue for light microscopy was fixed in $10 \% \frac{\bar{p}}{\vec{D}}$ formalin, and sections were stained with haemato- $\stackrel{\mathbb{Q}}{\varrho}$ xylin and eosin, Gram's stain, and periodic acidSchiff (PAS) with and without diastase treatment. Selected sections were stained for calcium by von Kossa's method and for iron with Perl's Prussian $\vec{\omega}$ blue. Tissues for electron microscopy (EM) came $\stackrel{9}{\Omega}$ from surgical specimens in cases 1 and 2 and were $\overline{0}$ fixed in $2.5 \%$ glutaraldehyde. Material for EM from iु case 3 came from necropsy tissue and was initially: fixed in $10 \%$ buffered formalin. All specimens were $\omega$

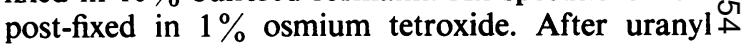
acetate staining and dehydration in graded alcohols, 음 the tissues were embedded in Epon and sections were stained with lead citrate.

The microscopic and EM findings were similar in all three cases and will be described together.

Microscopically, the predominant feature of the malacoplakic lesions was an infiltration of tissues by macrophages containing a characteristic eosinophilic granular cytoplasm and one or more rounded, weakly basophilic, concentrically laminated, cytoplasmic bodies, the M-G bodies (fig 1). The latter stained $\frac{\mathrm{O}}{\mathrm{D}}$ positively for calcium and weakly positive for iron $\stackrel{\varrho}{\Rightarrow}$ in cases 2 and 3 . The PAS reaction was positive in the $M-G$ bodies and in the cytoplasmic granules and remained positive after diastase digestion (fig 2) Gram stains revealed Gram-negative rods within the

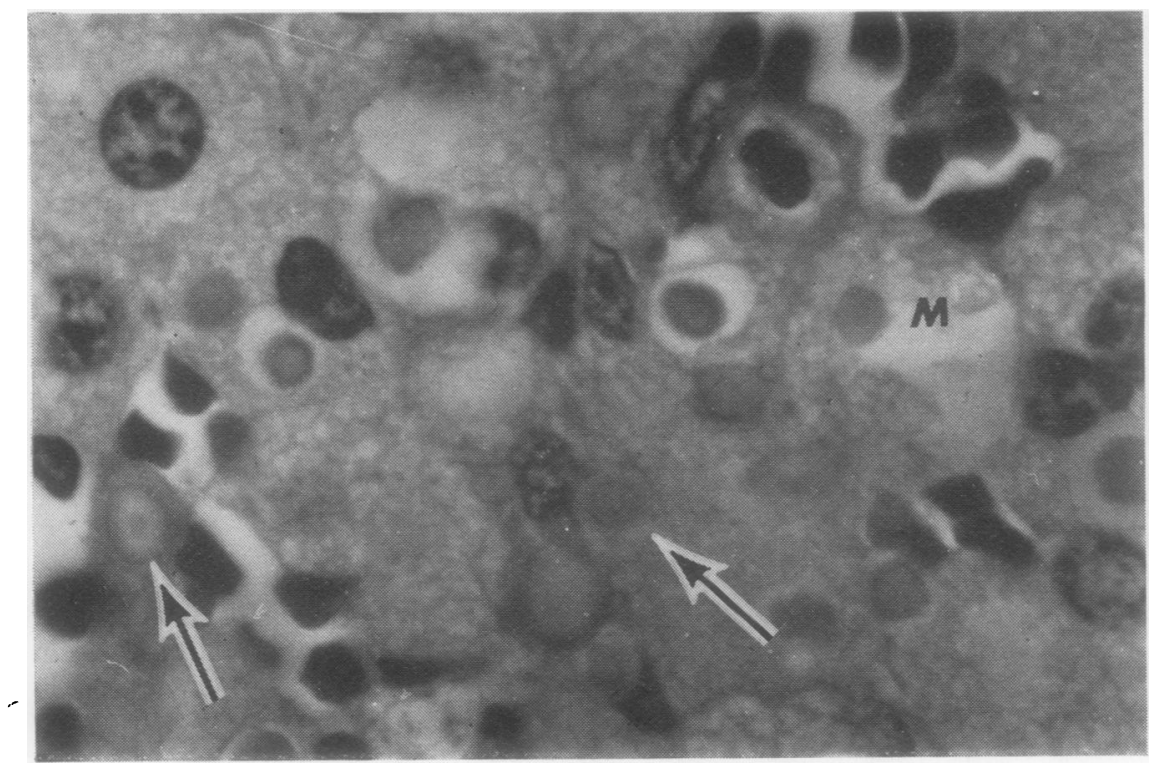

Fig 1 Case 1. Highpower photomicrograph of malacoplakia showing the malacoplakic cells $(M)$ with foamy cytoplasm and numerous MichaelisGutmann bodies (M-G) (arrows) (Haematoxylin and eosin $\times 1200$ ) 


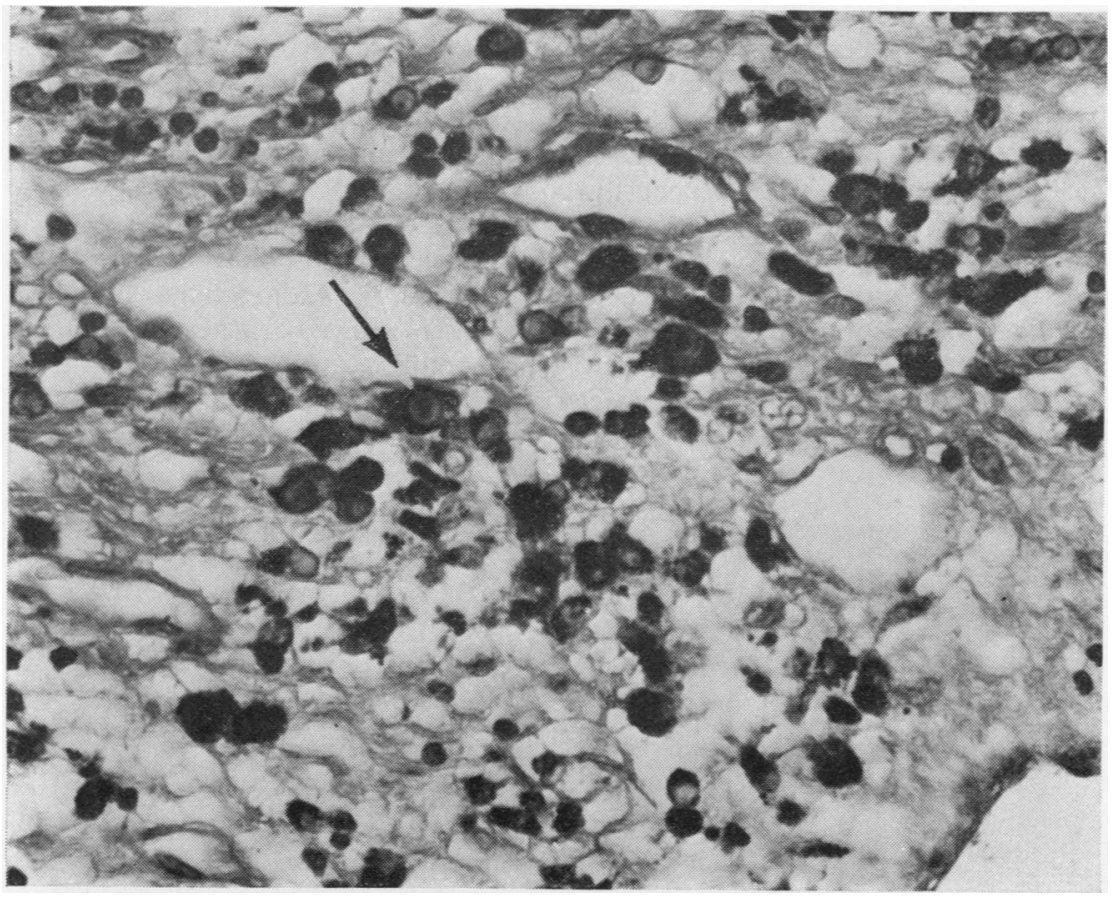

Fig 2 Malacoplakic cells stained with periodic acid Schiff $(P A S)$ to illustrate the dense staining of the granular cytoplasms. The $M-G$ bodies are also $P A S$ positive and some have a 'targetlike' appearance (arrow) $(\times 480)$

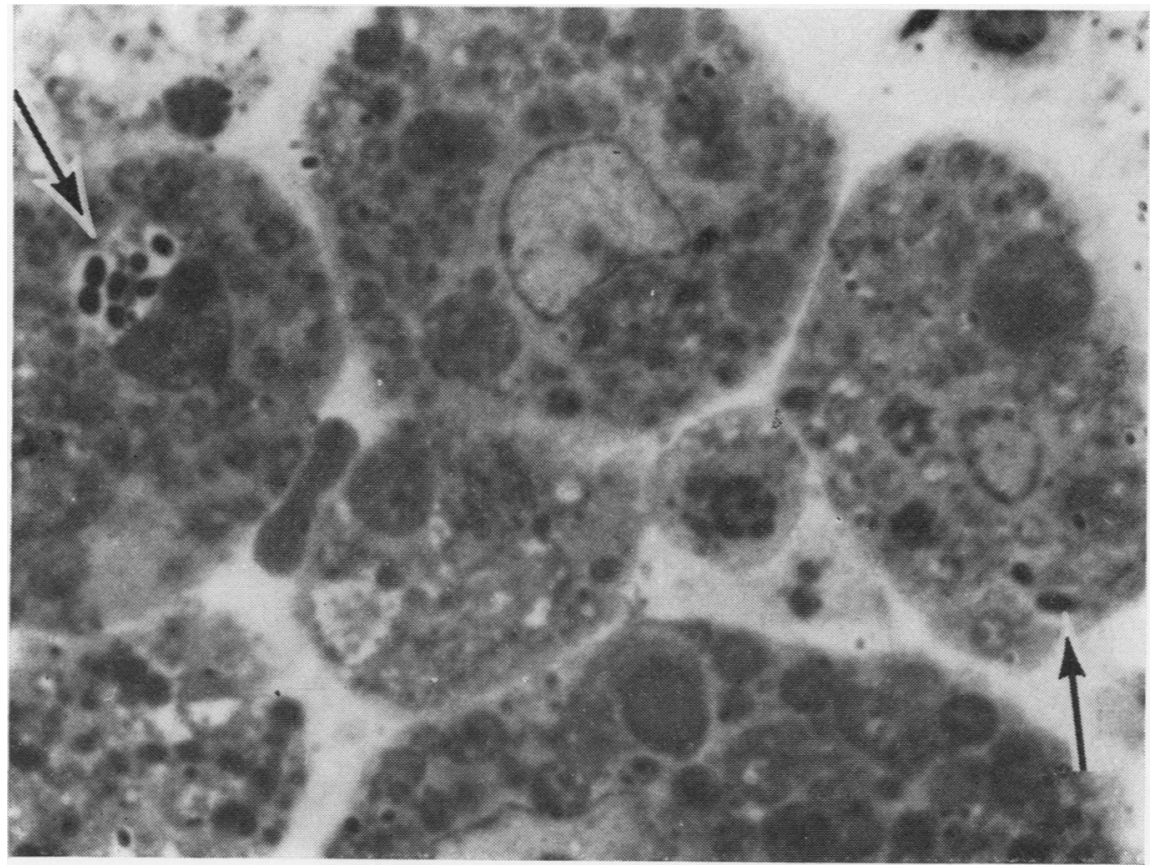

Fig 3 Photomicrograph of a $1 \mu$ Epon section to illustrate malacoplakic cells, two of which contain phagocytosed bacteria (arrows). Note the numerous cytoplasmic granules corresponding to the phagolysosomes on EM (toluidine blue $\times 1200)$ 
malacoplakic cells. Bacteria were also seen in the thick section of the Epon-embedded tissues and were especially numerous in cases 2 and 3 (fig 3). The other changes of malacoplakia consisted of a variable infiltrate of lymphocytes, plasma cells, and polymorphonuclear leucocytes which appeared to be dependent on the extent of accompanying tissue destruction.

Ultrastructurally the distinctive features of malacoplakia were the intracellular organisms, the numerous phagolysosomes, and the M-G bodies. In addition, the malacoplakic cells contained numerous mitochondria, abundant rough endoplasmic reti- $\frac{\text { 을 }}{-}$ culum, and a prominent Golgi apparatus. The intracellular bacteria had a bacilliform structure with $a \stackrel{\text { f }}{+}$ rigid cell wall and an irregular fibrillary nucleus. In? one case (case 2) a number of bacteria appeared $\frac{\bar{\sigma}}{\overline{\frac{D}{p}}}$ encapsulated.

The intracellular bacteria were found exclusively $\stackrel{\mathbb{D}}{\circ}$ in the malacoplakic cells within phagocytic vacuoles and phagolysosomes (fig 4). Although many bacteria $\vec{\circ}$ appeared intact, others showed degenerative changes:such as loss of cytoplasm, destruction of cell wall, $\vec{\omega}$ and bacterial fragmentation with clumping of

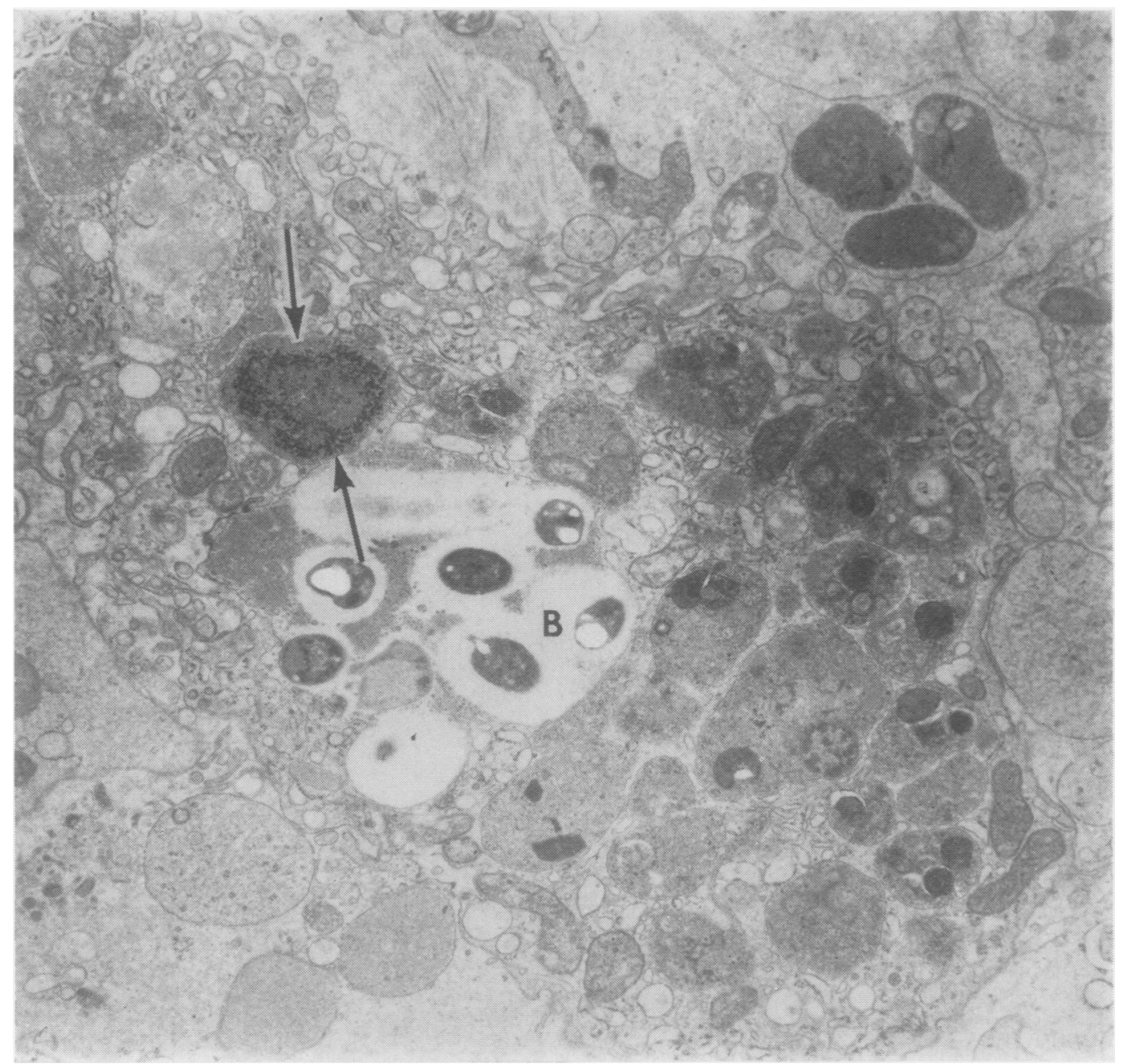

Fig 4 Electron micrograph of a typical malacoplakic cell to illustrate the numerous intracellular bacteria (B), many of which lie within cytoplasmic phagolysosomes. Many of the electron-dense masses within the phagolysosomes probably represent incompletely digested bacteria. Note also the small M-G body (arrows) $(\times 4000)$ 
cytoplasm (fig 5). Some of the bacterial fragments were closely appositioned to whorled intralysosomal membranes and some were occasionally seen in the centre of myelin-like figures. Although the majority of phagocytic vacuoles contained phagocytosed bacteria, occasionally other structures such as cell nuclei were identified.

The cytoplasmic inclusions corresponding to the PAS-positive granules consisted of phagolysosomes (figs 3 and 4). They varied in size from 0.5 to $10 \mu$, and the larger ones appeared to form by coalescence of the smaller lysosomal inclusions. The phagolysosomes were lined by a single limiting membrane and were filled with phospholipid membranes forming complex membranous whorls, myelin figures and occasional vesicles. Many phagolysosomes also contained numerous electron-dense bodies, measuring about $0.5 \mu$ in diameter, which probably represent residual bacteria remnants although no longer clearly recognizable as such (fig 4). The M-G bodies appeared to develop within the phagolysosomes. The earliest visible change appeared to be smudging of the intraphagolysosomal structures due to calcium deposition (fig 6). Further deposition of calcium appeared to produce irregular electron-dense amorphous masses within the phagolysosomes. In the intermediate stages of development the M-G bodies appeared as larger, spiculated, round,

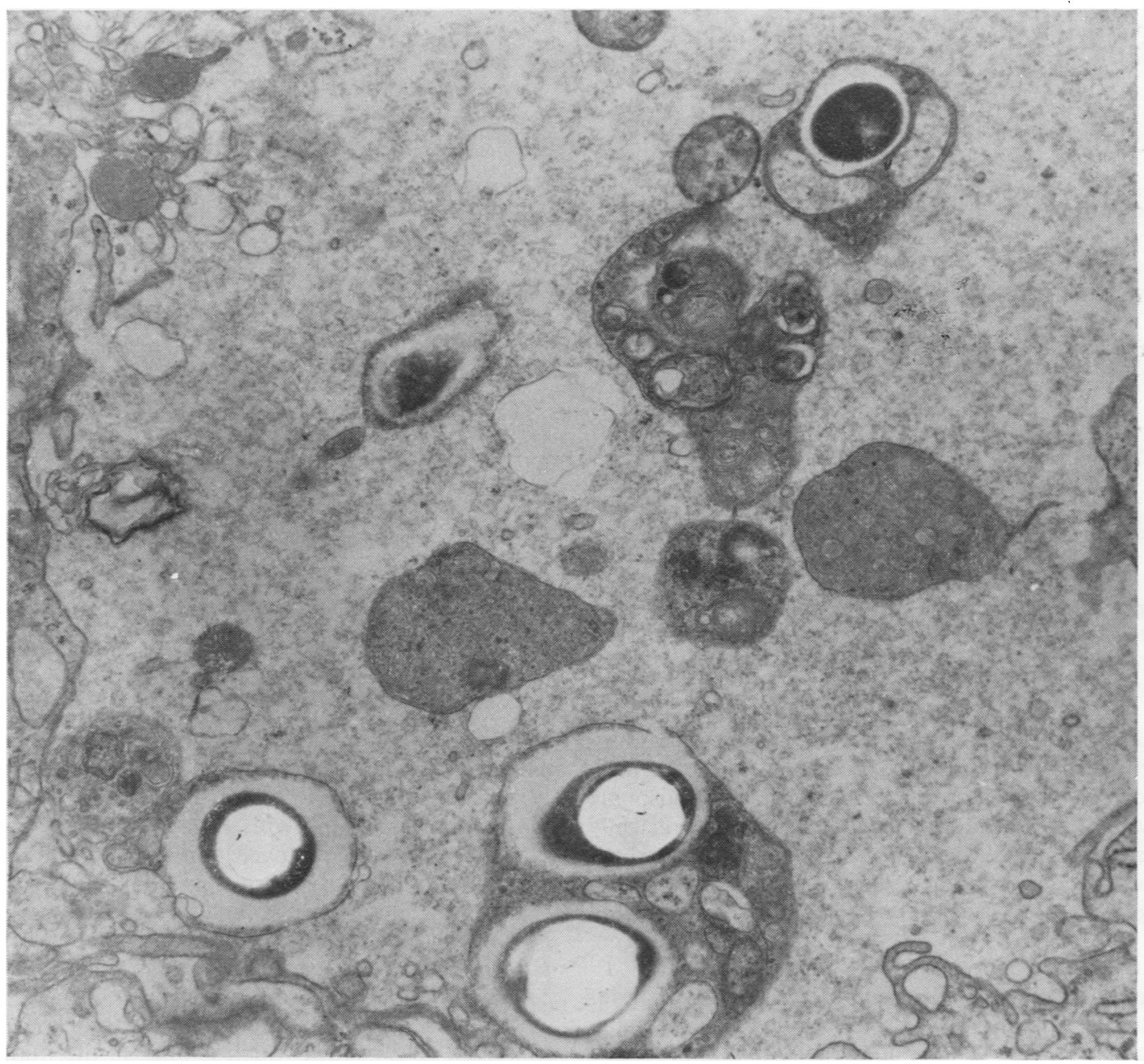

Fig 5 Electron micrograph of malacoplakic phagolysosomes to illustrate bacteria in varying stages of degeneration. Also note the complex membranous whorls which are prominent in some of the phagolysosomes $(\times 11000)$ 


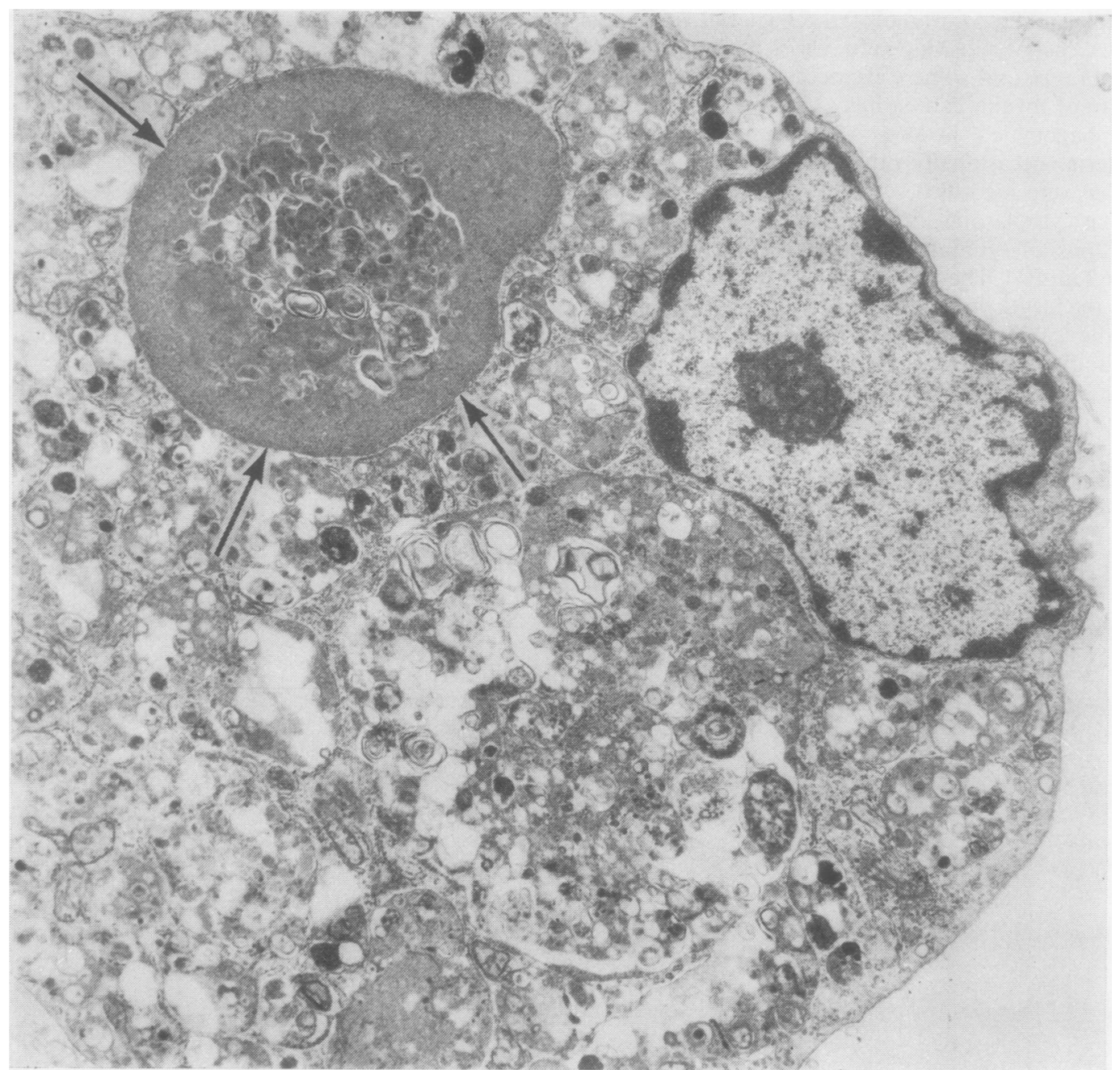

Fig 6 Electron micrograph of a malacoplakic cell illustrating the smudging of outlines of a phagolysosome (arrows) probably due to calcium deposition and representing the early stage of development of the M-G body. Note also the wide variation in size of the phagolysosomes $(\times 4000)$

electron-dense masses. In the late stages of development, growth of the M-G bodies appeared to have occurred by concentric layering of calcium phosphate crystals to produce the typical concentrically laminated calculospherules corresponding to the 'owl-eye' M-G bodies seen on light microscopy (fig 7).

\section{LEUCOCYTE FUNCTION STUDIES}

Mononuclear cells were separated from the granulocytes in the peripheral blood of case 2 using a Ficoll-Hypaque gradient as previously described (Steigbigel et al, 1974). The bactericidal capacity of the patient's monocytes and polymorphonuclear leucocytes was compared to that of a healthy contro? using a method previously described (Steigbigel et al ${ }^{\text {N }}$ 1974). Monocytes and medium with $10 \%$ autologous serum were incubated with $E$. coli, and at 2 and 40 hours samples were removed, sonicated, diluted, ando plated onto trypticase soy agar. The bactericida $F_{0}$ capacity of the patient's and a control subject's? polymorphonuclear leucocytes was studied usingo E. coli, Salmonella tryphimurium (strain $\mathrm{C}_{5} \mathrm{~S}$ ), and? Staphylococcus aureus-502A.

The effect of monocytes on the growth of $E$. coli is expressed as an index which compares the numbero of colony-forming units present in suspensions containing monocytes to the number of colony 


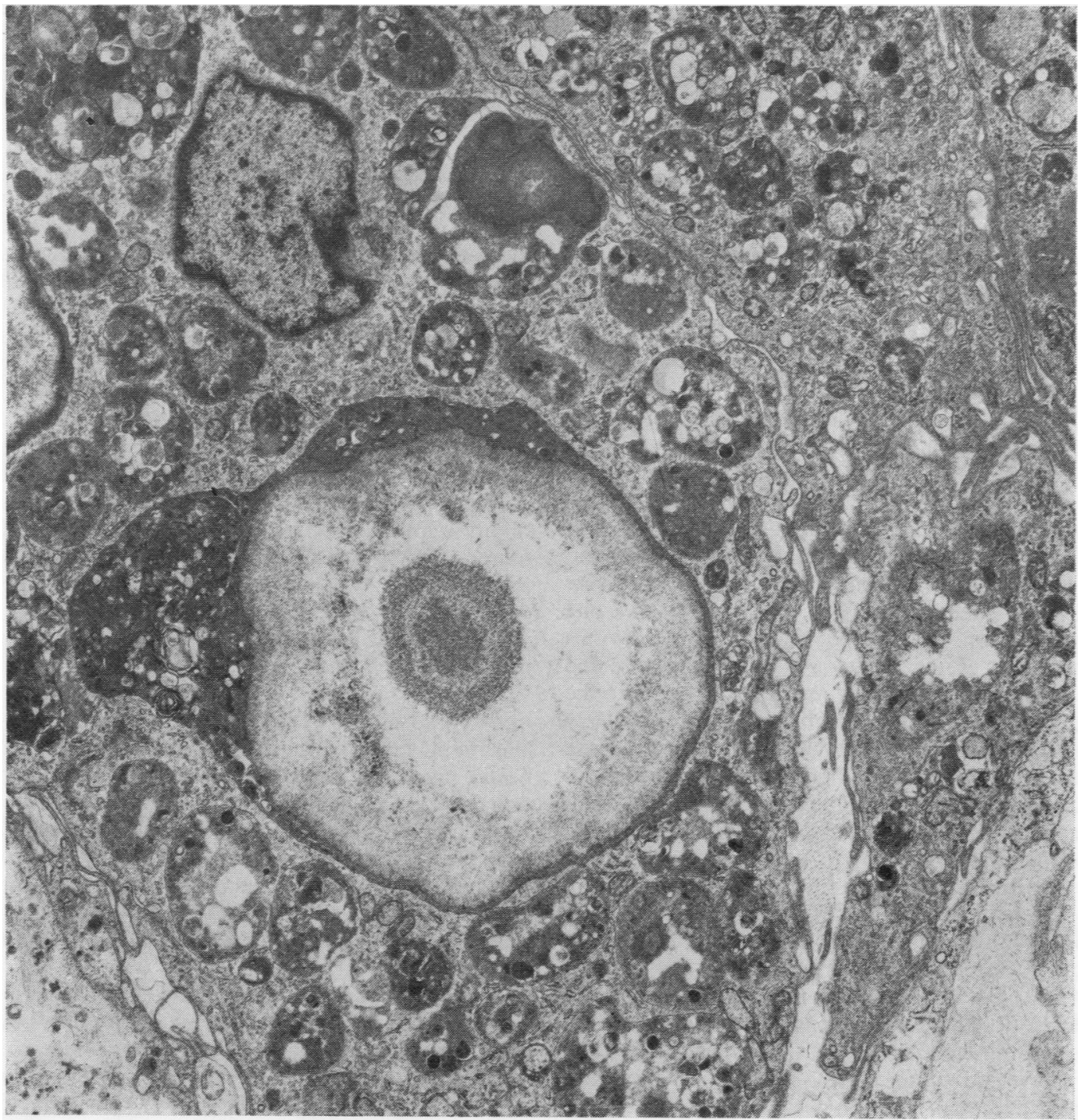

Fig 7 Electron micrograph of a fully formed M-G body illustrating the concentric lamination of calcium phosphate crystals corresponding to the 'owl-eye' appearance of $M$ - $G$ bodies seen on light microscopy. Note residual lysosomal structures at periphery of $M-G$ body $(\times 7000)$

forming units in control suspensions containing no monocytes but the same medium. The use of the index compensates for the variability of growth of non-phagocytized organisms in the medium and serum of different subjects (Steigbigel et al, 1974). Since there are insignificant numbers of non-phagocytized organisms in suspensions with neutrophils, the data for neutrophils are expressed as the percentage of initial inoculum of bacteria killed at 2 and 4 hours. The results are shown in table II. There is no significant difference between the patient's and the control subject's monocyte killing of $E$. coli or between the patient's and control subject's polymorphonuclear leucocyte killing of E. coli, Staph. aureus, and $S$. typhimurium.

\section{Discussion}

Histochemical and clinical studies have suggested that malacoplakia has an infectious origin. This 


\begin{tabular}{|c|c|c|c|c|c|}
\hline \multirow[t]{2}{*}{ Organism } & \multirow[t]{2}{*}{ Hours } & \multicolumn{2}{|c|}{ Monocytes $^{1}$} & \multicolumn{2}{|c|}{$\begin{array}{l}\text { Polymorphonuclear } \\
\text { Leucocytes }^{2}\end{array}$} \\
\hline & & Patient & Control & Patient & Control \\
\hline \multirow[t]{2}{*}{ E. coli } & 2 & 75 & 54 & $99 \cdot 3$ & $99 \cdot 7$ \\
\hline & 4 & 46 & 67 & $99 \cdot 3$ & 99.9 \\
\hline \multirow[t]{2}{*}{ S. typhimurium } & 2 & & & $97 \cdot 9$ & 95.4 \\
\hline & 4 & & & $99 \cdot 5$ & 95.4 \\
\hline \multirow[t]{2}{*}{ Staph. aureus } & 2 & & & $90 \cdot 6$ & $74 \cdot 2$ \\
\hline & 4 & & & $97 \cdot 6$ & $95 \cdot 3$ \\
\hline
\end{tabular}

Table II Bactericidal capacity of monocytes and polymorphonuclear leucocytes from case 2 and control subjects

${ }^{1}$ Results for monocytes expressed as index as discussed in text ${ }^{2}$ Results for neutrophils expressed in percentage of initial inoculum killed

suggestion has been supported by electron microscopy (Le Charpentier et al, 1973; Lewin et al, 1974; Lou and Teplitz, 1974). Our ultrastructural studies reveal bacilliform organisms, within the malacoplakic macrophages, in various states of degradation and sometimes in close apposition to phospholipid membranes. The electron microscopic changes were seen in all three of our cases irrespective of the site of the lesion. They corroborate our previous observations of malacoplakia in which we postulated that phagocytosed bacteria are incorporated into the phagolysosomes of macrophage but incompletely digested. The bacterial remnants persist as dense amorphous aggregates and phospholipid membranes which later appear to become encrusted with calcium phosphate crystals to form the laminated M-G bodies (Lewin et al, 1974).

It is puzzling why the macrophages only rarely respond in this unusual fashion to ap apparently common infectious agent. We have previously suggested three possible explanations (Lewin et al, 1974): (1) The organisms may be an usual strain of bacteria. (2) The lesion is related to an abnormality affecting intracellular killing. (3) The macrophages may have an abnormality affecting intracellular digestion.

NATURE OF THE ORGANISM

Coliforms have long been suspected in malacoplakia because of the frequent association of $E$. coli urinary tract infection with this disorder (Gonzáles-Angulo et $a l, 1965)$ and the response of many cases of malacoplakia to antibiotic therapy (Curtis et al, 1961; Lambird and Yardley, 1970). In all three of our cases significant numbers of $E$. coli were isolated. In case 2 the organism was isolated from both the urine and the crushed biopsy specimen and identified by serotyping as types 02 and 050 . Both of these coliforms are common strains and not particularly virulent, indicating that malacoplakia is not caused by infection with an unusual strain of bacterium. In fact the type of bacterium associated with malaco- $\stackrel{\stackrel{*}{*}}{\circ}$ plakia may not be of prime importance since there have been reports of malacoplakia in which other $\overrightarrow{\vec{m}}$ Gram-negative enteric organisms such as Klebsiella were found (Lou and Teplitz, 1974).

IMMUNOLOGICAL STATUS

Although clinically all three patients had diseases

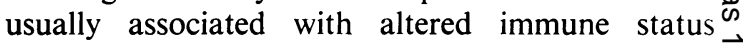
(namely, sarcoidosis, lymphoma, and carcinoma),. in only one of the two patients investigated could an $\overrightarrow{\vec{\omega}}$ abnormality of humoral immunity be detected. This $\stackrel{\omega}{\circ}$ patient (case 1) had severely depressed serum옹 immunoglobulins (IgA, IgM, and IgG) and anergy is to the usual skin tests (table I). These abnormalities were probably related to the patient's underlying $\dot{\omega}$ lymphoma and chemotherapy, both of which are associated with hypogammaglobulinaemia and $\mathrm{O}$ immune deficiency. The second patient had slightly raised immunoglobulins, a positive skin test for $D$ mumps, and a normal PHA lymphocyte stimulation test. Although we could not detect any immune $\vec{\bullet}$ deficiency in this patient, the medical history of sarcoidosis was suggestive of an earlier compromise in the immune system.

\section{LEUCOCYTE FUNCTION}

We found no abnormality in the killing of $E$. coli, Staph. aureus, or S. typhimurium by the polymorph- $\mathbb{Q}$ onuclear leucocytes of case 2. These cells are of $\overrightarrow{\overrightarrow{0}}$ primary importance in the killing of Gram-negative 3 organisms such as E. coli. They also kill facultative intracellular organisms such as Salmonella more rapidly than do peripheral blood monocytes (Steigbigel et al, 1974). These data suggest that the development of malacoplakia is not due to an abnormality in the patient's neutrophil bactericidal capacity. The presence of such an abnormality could potentially cause overloading of macrophages with 0 viable organisms. We found no indication of abnormal T lymphocyte responsiveness to PHA or monocyte bactericidal capacity in case 2 .

The possibility remains that the macrophages of $\mathcal{N}$ these patients have an abnormality in the digestion $N$ of killed bacteria. Further studies which examine the N quantity and qualitative function of intracellular $\sigma$ enzymes of monocyte and macrophage from patients with malacoplakia are needed.

\section{References}

Blackshear, W. M., Jr. (1970). Malakoplakia of the appendix: a case report. Amer. J. clin. Path., 53, 284-287.

Blackwell, J. B. and Finlay-Jones, L. R. (1959). Malakoplakia $\frac{\rho}{\Phi}$ of the testis: report of a case. J. Path. Bact., 78, 571-574.

Bleisch, V. R. and Konikov, N. F. (1952). Malakoplakia of the urinary bladder. Arch. Path., 54, 388-397.

Curtis, W. R., Bozzell, J. D., and Green, C. L. (1961).O 
Malacoplakia of bladder: report of a case successfully treated with anti-tuberculous medical therapy. J. Urol. (Baltimore), 86, 78-81.

Di Silvio, T. V. and Bartlett, E. F. (1971). Malakoplakia of the colon. Arch. Path., 92, 167-171.

Dockerty, M. B. (1972). Primary malakoplakia of the colon. Mayo Clin. Proc., 47, 114-116.

Finlay-Jones, L. R., Blackwell, J. B., and Papadimitriou, J. M. (1968). Malakoplakia of the colon. Amer. J. clin. Path., 50, 320-329.

Gonzáles-Angulo, A., Corral, E., García-Torres, R., and Quijano, M. (1965). Malacoplakia of the colon. Gastroenterology, 48, 383-387.

Green, W. O. (1968). Malacoplakia of the epididymis (without testicular involvement): the first reported case. Arch. Path., 86, 438-441.

Gupta, R. K., Schuster, R. A., and Christian, W. D. (1972). Autopsy findings in a unique case of malacoplakia. Arch. Path., 93, 42-48.

von Hansemann, D. (1903). Über Malakoplakie der Harnblase. Virchows Arch. path. Anat., 173, 302-308.

Haukohl, R. S. and Chinchinian, H. (1958). Malakoplakia of the testicle: report of a case. Amer. J. clin. Path., 29, 473-478.

Hoffman, E. and Garrido, M. (1964). Malakoplakia of the prostate: report of a case. J. Urol., 92, 311-313.

Lambird, P. A. and Yardley, J. H. (1970). Urinary tract malakoplakia: report of a fatal case with ultrastructural observations of Michaelis-Gutman bodies. Johns Hopkins med.J., 126, 1-14.

Le Charpentier, Y., Le Carpentier, M., Franc, B., Galian, P. and Abelanet, R. (1973). Données fournies par l'étude ultrastructurale de deux observations de malakoplakie. Virchows Arch. path. Anat., 359, 157-170.

Leclerc, J. L. and Bernier, L. (1972). Malacoplasie cutanée. Un. méd. Can., 101, 471-473.

Lewin, K. and Fair, W. (1974). Malacoplakia: some aspects of etiology and pathogenesis (Abstract). Amer. J. Path., 74, 55a.

Lewin, K. J., Harell, G. S., Lee, A. S., and Crowley, L. G. (1974). Malacoplakia: an electron microscopic study: demonstration of bacilliform organisms in malacoplakic macrophages. Gastroenterology, 66, 28-45.

Lou, T. Y. and Teplitz, C. (1974). Malacoplakia, pathogenesis and ultra-structural morphogenesis: a problem of altered macrophage (phagolysosomal) response. Hum. Path., 5, 191-207.

McClurg, F. V., D'Agostino, A. N., Martin, J. H., and Race, G. J. (1973). Ultrastructural demonstration of intracellular bacteria in 3 cases of malakoplakia of the bladder. Amer. J. clin. Path., 60, 780-788.

Melicow, M. M. (1957). Malakoplakia: report of a case; review of literature. J. Urol., 78, 33-40.

Michaelis, L. and Gutmann, C. (1902). Ueber Einschlüsse in Blasentumoren. Z. klin. Med., 47, 208-215.

Nation, E. F. (1956). Malakoplakia of the urinary tract. J. Urol., 76, 576-582.

Ranchod, M. and Kahn, L. B. (1972). Malacoplakia of the gastrointestinal tract. Arch. Path., 94, 90-97.

Rywlin, A. M., Ravel, R., and Hurwitz, A. (1969). Malakoplakia of the colon. Amer. J. dig. Dis., 14, 491-499.

Scott, E. V. Z., and Scott, W. F. Jr. (1958). A fatal case of malakoplakia of the urinary tract. J. Urol., 79, 52-56.

Smith, B. H. (1965). Malacoplakia of the urinary tract: a study of twenty-four cases. Amer.J. clin. Path., 43, 409-417.

Steigbigel, R. T., Lambert, L. H., Jr., and Remington, J. S. (1974). Phagocytic and bactericidal properties of normal human monocytes. J. clin. Invest, 53, 131-142.

Terner, J. Y. and Lattes, R. (1965). Malakoplakia of colon and retroperitoneum: report of a case with a histochemical study of the Michaelis-Gutmann inclusion bodies. Amer.J. clin. Path., 44, 20-31.

Waisman, J. and Rampton, J. B. (1968). Malacoplakia of the testis and epididymis. Arch. Path., 86, 431-437.

Yunis, E. J., Estevez, J. M., Pinzon, G. J., and Moran, T. J. (1967). Malacoplakia: discussion of pathogenesis and report of three cases including one of fatal gastric and colonic involvement. Arch. Path., 83, 180-187.

Address requests for reprints to Dr Klaus Lewin, MD, Department of Pathology, Room L235, Stanford University School of Medicine, Stanford, California 94305, USA 